\title{
Land Use Planning for Natural Hazards
}

\author{
George D. Bathrellos * (1) and Hariklia D. Skilodimou \\ Department of Geography and Climatology, Faculty of Geology and Geoenvironment, National and \\ Kapodistrian University of Athens, University Campus, Zografou, ZC 15784 Athens, Greece \\ * Correspondence: gbathrellos@geol.uoa.gr; Tel.: +30-2107274882
}

Received: 17 August 2019; Accepted: 23 August 2019; Published: 25 August 2019

The Earth's landscape has a complex evolution and is the result of the interactions involving surficial processes, climate, tectonic, and human activity. In this context, the morphological changes in landforms due to active tectonics or climate change have the potential to affect and, in some cases, even to control human activities [1-5]. On the other hand, human activity and man-made constructions have the ability to change the landscape and, in this way, have impacted on natural hazards.

Natural hazards are physical phenomena that occur worldwide and contribute to the evolution of Earth's landscape. These phenomena affected the natural environment and existing biota, even before the appearance of man on Earth. Nowadays, they are an important global problem threatening human life. Natural hazards can damage both the natural and man-made environment [6]. Their impacts differ from place to place and frequently they appear to have adverse long-term effects [7].

On a global scale, overpopulation and urban development have the ability to increase the occurrence of natural hazards and their impacts both in the developed and developing world. For instance, deforestation causes increased rates of soil erosion and sediment transport, resulting in, for example, land degradation and flooding. Generally, natural hazards occur more frequently in relation to our capability to restore the effects of past events [8-10].

The sustainability of urban development can be influenced by several factors such as economic development, socioeconomic policy, population growth, physical environment, and natural hazards [11,12]. However, during planning, development, and management of an urban environment, only the economic and social parameters are usually taken into account. Consequently, in vulnerable locations, e.g., steeply sloping areas or those with degraded soils, the natural hazards that often occur, such as mass movements, can cause extensive damage, disrupt social and economic networks and lead to the loss of human lives and property [13-17].

Therefore, in order to minimize the loss of human life and reduce the economic consequences, proper planning and management of natural hazards are essential. However, consideration of the natural hazards and their influence on landscape evolution during the land use planning stage is essential.

In many cases, land use planning for addressing natural hazards is based on the probability of an event occurring, with little or no consideration of the consequences associated with natural hazard events [18]. For instance, floodplains are fertile, level, easy to excavate, near water and, thus, are favorable sites for urban development. In several cases, urbanization of floodplains has increased the probability of flooding, thereby causing disasters. Flood damage in such environments appears to increase, despite the construction of flood control works such as dams and river channelization [19-22].

The relationship between natural hazards and land use seems to be two-way. On the one hand, natural hazards and their associated consequences have the ability to cause changes in the landscape and thus, affect land use. On the other hand, human activities and land-use changes can lead to natural hazards.

In order to avoid the aforementioned effects, it is necessary for the decision-makers, engineers, planners, and managers to take into account the physical parameters of an area, as well as susceptibility 
to the natural hazards. The geology and the geomorphology of an area are important in the assurance of sustainable land management and in the protection of human life in urban areas [23].

In conclusion, is important that engineers, policymakers, and planners employ land use planning based on natural hazard maps in the evaluation and selection of suitable areas for sustainable urban development with fundamental concerns for the protection of the environment and of human life.

This special issue focuses on land use planning for natural hazards. Various types of natural hazards such as land degradation and desertification, coastal hazard, floods, and landslides, as well as their interactions with human activities, are presented in this volume.

Briassoulis H. [24] examines the use of Land Use Planning (LUP) to combat Land Degradation and Desertification (LDD). Various and interdependent socio-economic, cultural, political and institutional criteria play an important role in LDD or contribute to the management of land resources [25]. The paper presents desertification and the pertinent institutional context and studies whether and how LDD concerns enter the LUP process and the issues arising at each stage. The provision of an enabling, higher-level institutional environment should be prioritized to support phronetic-strategic integrated LUP at lower levels, which future research should explore theoretically, methodologically and empirically to realize the integrative potential of LUP and foster its effectiveness in combating LDD at the local and regional levels.

Tragaki, et al. [26] assess coastal hazard vulnerability based on geomorphic, oceanographic and demographic parameters in the Peloponnese (southern Greece). Nowadays, coastal areas around Greece are susceptible to climate change-related hazards [27]. The paper assesses the physical and social vulnerability of the Peloponnese to both coastal erosion and flooding caused by climate change-related hazards. The Coastal Vulnerability Index (CVI) and the Social Vulnerability Index (SVI) were estimated. The results showed that about $20 \%$ of the shoreline along the western and northwestern coast of the study area has high and very high physical vulnerability. Moreover, high and very high social vulnerabilities characterize communities along the northwestern part of the Peloponnese. The recognition of highly vulnerable coastal areas is very useful for coastal land use planning.

Two papers apply methods that provide vital information for land use planning and flood hazard mitigation. Rijal et al. [28] examine flood hazard mapping in the rapidly urbanizing city of Birendranagar, Nepal. Natural hazards and urbanization can interact to increase land-use changes in Nepal [29], and floods have caused loss of life and property in Birendranagar. The study focuses on the underlying land-cover dynamics and flood hazards of the study area. The spatiotemporal urbanization dynamics and associated land-use and land-cover (LULC) changes of the city from 1989 to 2016 allowed areas with high flood hazard risk to be identified. The urban area expanded nearly by $700 \%$, while the cultivated land declined simultaneously by $12 \%$ between 1989 and 2016. This, and the loss of forests contributed significantly to increased flood hazard. Steep slopes, excessive land utilization, and intense monsoonal precipitation aggravated hazards locally.

Bathrellos et al. [30] undertake spatio-temporal analysis of flooding in the drainage basin of the Pinios River (Thessaly, Central Greece). The paper identifies the flood hazard by using historical flood events which occurred between 1979 and 2010, old topographic maps and geomorphic parameters. The flood occurrences increased during the period 1990-2010, most flood events were in October. The majority of occurrences are recorded in the southern part of the study area. There is a certain amount of clustering of flood events in the areas of former marshes and lakes as well as in the lowest and flattest parts of the study area. The applied method provides valuable information for land-use planning at a regional scale leading to the determination of the safe and non-safe areas for urban activities.

Skilodimou et al. [31] examine the relation of physical and anthropogenic factors with landslide activity in a mountainous part of northern Peloponnese in southern Greece. The existing landslides, lithology, slope angle, rainfall, road network along with land use of the study area were analyzed. The results prove that Plio-Pleistocene fine-grained sediments and flysch, relatively steep slopes and a rise in the amount of rainfall are strongly associated with the occurrence of landslides. A 100m wide 
zone along each road increases the probability of landslides while the extensively cultivated land of the study area is strongly related to landslide activity. This procedure may be utilized in landslide hazard assessment mapping as well as to new and existing land use planning projects.

Conflicts of Interest: The authors declare no conflict of interest.

\section{References}

1. Bathrellos, G.D.; Skilodimou, H.D.; Maroukian, H. The spatial distribution of Middle and Late Pleistocene cirques in Greece. Geogr. Ann. A 2014, 9, 323-338. [CrossRef]

2. Skilodimou, H.D.; Bathrellos, G.D.; Maroukian, H.; Gaki-Papanastassiou, K. Late Quaternary evolution of the lower reaches of Ziliana stream in south Mt. Olympus (Greece). Geogr. Fis. Din. Quat. 2014, 37, 43-50.

3. Kokinou, E.; Skilodimou, H.D.; Bathrellos, G.D.; Antonarakou, A.; Kamberis, E. Morphotectonic analysis, structural evolution/pattern of a contractional ridge: Giouchtas Mt., Central Crete, Greece. J. Earth Syst. Sci. 2015, 124, 587-602. [CrossRef]

4. Bathrellos, G.D.; Skilodimou, H.D.; Maroukian, H. The significance of tectonism in the glaciations of Greece. Geol. Soc. Spec. Publ. 2017, 433, 237-250. [CrossRef]

5. Bathrellos, G.D.; Skilodimou, H.D.; Maroukian, H.; Gaki-Papanastassiou, K.; Kouli, K.; Tsourou, T.; Tsaparas, N. Pleistocene glacial and lacustrine activity in the southern part of Mount Olympus (central Greece). Area 2017, 49, 137-147. [CrossRef]

6. Bathrellos, G.D.; Skilodimou, H.D.; Chousianitis, K.; Youssef, A.M.; Pradhan, B. Suitability estimation for urban development using multi-hazard assessment map. Sci. Total Environ. 2017, 575, 119-134. [CrossRef] [PubMed]

7. Alcántara-Ayala, I. Geomorphology, natural hazards, vulnerability and prevention of natural disasters in developing countries. Geomorphology 2002, 47, 107-124. [CrossRef]

8. Guzzetti, F.; Carrara, A.; Cardinali, M.; Reichenbach, P. Landslide hazard evaluation: A review of current techniques and their application in a multi-scale study, Central Italy. Geomorphology 1999, 31, 181-216. [CrossRef]

9. Tsolaki-Fiaka, S.; Bathrellos, G.D.; Skilodimou, H.D. Multi-criteria decision analysis for abandoned quarry restoration in Evros Region (NE Greece). Land 2018, 7, 43. [CrossRef]

10. Skilodimou, H.D.; Bathrellos, G.D.; Chousianitis, K.; Youssef, A.M.; Pradhan, B. Multi-hazard assessment modeling via multi-criteria analysis and GIS: A case study. Environ. Earth Sci. 2019, 78, 47. [CrossRef]

11. Fedeski, M.; Gwilliam, J. Urban sustainability in the presence of flood and geological hazards: The development of a GIS-based vulnerability and risk assessment methodology. Landsc. Urban Plan. 2007, 83, 50-61. [CrossRef]

12. Thapa, R.B.; Murayama, Y. Drivers of urban growth in the Kathmandu Valley, Nepal: Examining the efficacy of the analytic hierarchy process. Appl. Geogr. 2010, 30, 70-83. [CrossRef]

13. Bathrellos, G.D.; Kalivas, D.P.; Skilodimou, H.D. Landslide susceptibility mapping models, applied to natural and urban planning, using G.I.S. Estud. Geol.-Madrid 2009, 65, 49-65. [CrossRef]

14. Rozos, D.; Bathrellos, G.D.; Skilodimou, H.D. Comparison of the implementation of Rock Engineering System (RES) and Analytic Hierarchy Process (AHP) methods, based on landslide susceptibility maps, compiled in GIS environment. A case study from the Eastern Achaia County of Peloponnesus, Greece. Environ. Earth Sci. 2011, 63, 49-63. [CrossRef]

15. Bathrellos, G.D.; Gaki-Papanastassiou, K.; Skilodimou, H.D.; Skianis, G.A.; Chousianitis, K.G. Assessment of rural community and agricultural development using geomorphological-geological factors and GIS in the Trikala prefecture (Central Greece). Stoch. Environ. Res. Risk Assess. 2013, 27, 573-588. [CrossRef]

16. Papadopoulou-Vrynioti, K.; Bathrellos, G.D.; Skilodimou, H.D.; Kaviris, G.; Makropoulos, K. Karst collapse susceptibility mapping considering peak ground acceleration in a rapidly growing urban area. Eng. Geol. 2013, 158, 77-88. [CrossRef]

17. Bathrellos, G.D.; Kalivas, D.P.; Skilodimou, H.D. Landslide Susceptibility Assessment Mapping: A Case Study in Central Greece. In Remote Sensing of Hydrometeorological Hazards; Petropoulos, G.P., Islam, T., Eds.; CRC Press, Taylor \& Francis Group: London, UK, 2017; pp. 493-512, ISBN-13: 978-1498777582. 
18. Saunders, W.S.; Kilvington, M. Innovative land use planning for natural hazard risk reduction: A consequence-driven approach from New Zealand. Int. J. Disaster Risk Reduct. 2016, 18, $244-255$. [CrossRef]

19. Bathrellos, G.; Skilodimou, H. Geomorphic Hazards and Disasters. Bull. Geol. Soc. Greece 2006, 39, 96-103. (In Greek)

20. Goudie, S.A. Encyclopedia of Geomorphology; Goudie, S.A., Ed.; Taylor \& Francis Group: New York, NY, USA, 2006; pp. 378-379.

21. Bathrellos, G.D. An overview in Urban Geology and Urban Geomorphology. Bull. Geol. Soc. Greece 2007, 40, 1354-1364. [CrossRef]

22. Bathrellos, G.D.; Karymbalis, E.; Skilodimou, H.D.; Gaki-Papanastassiou, K.; Baltas, E.A. Urban flood hazard assessment in the basin of Athens Metropolitan city, Greece. Environ. Earth Sci. 2016, 75, 319. [CrossRef]

23. Bathrellos, G.D.; Gaki-Papanastassiou, K.; Skilodimou, H.D.; Papanastassiou, D.; Chousianitis, K.G. Potential suitability for urban planning and industry development by using natural hazard maps and geological-geomorphological parameters. Environ. Earth Sci. 2012, 66, 537-548. [CrossRef]

24. Briassoulis, H. Combating Land Degradation and Desertification: The Land-Use Planning Quandary. Land 2019, 8, 27. [CrossRef]

25. Briassoulis, H. Desertification. In Science and Policy. An A to Z Guide to Issues and Controversies; Steel, B., Ed.; CQ Press: Thousand Oaks, CA, USA, 2014; pp. 138-145.

26. Tragaki, A.; Gallousi, C.; Karymbalis, E. Coastal hazard vulnerability assessment based on geomorphic, oceanographic and demographic parameters: The case of the Peloponnese (Southern Greece). Land 2018, 7, 56. [CrossRef]

27. Karymbalis, E.; Chalkias, C.; Chalkias, G.; Grigoropoulou, E.; Manthos, G.; Ferentinou, M. Assessment of the sensitivity of the southern coast of the Gulf of Corinth (Peloponnese, Greece) to sea-level rise. Cent. Eur. J. Geosci. 2012, 4, 561-577. [CrossRef]

28. Rijal, S.; Rimal, B.; Sloan, S. Flood hazard mapping of a rapidly urbanizing city in the foothills (Birendranagar, Surkhet) of Nepal. Land 2018, 7, 60. [CrossRef]

29. Rimal, B.; Zhang, L.; Keshtkar, H.; Sun, X.; Rijal, S. Quantifying the Spatiotemporal Pattern of Urban Expansion and Hazard and Risk Area Identification in the Kaski District of Nepal. Land 2018, 7, 37. [CrossRef]

30. Bathrellos, G.D.; Skilodimou, H.D.; Soukis, K.; Koskeridou, E. Temporal and spatial analysis of flood occurrences in drainage basin of Pinios River (Thessaly, central Greece). Land 2018, 7, 106. [CrossRef]

31. Skilodimou, H.D.; Bathrellos, G.D.; Koskeridou, E.; Soukis, K.; Rozos, D. Physical and anthropogenic factors related to landslide activity in the Northern Peloponnese, Greece. Land 2018, 7, 85. [CrossRef] 